\title{
Gender and the history of religion \\ New approaches and recent studies
}

\section{Af Edith SAurer}

Does a critical discussion of globalization need a critical anlaysis of interreligious relationships? And what is the role of gender relations in this context?

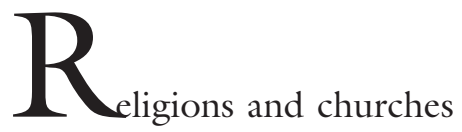
were subjects that women's studies addressed early on, for it was in them that patriarchy developed at its most genuine, so to speak, because justified on sacred grounds, a male God and a male hierarchy. It was feminist theologians who were the first to speak up and who, by taking as their subject the situation of women in the churches, gained rapidly in self-assurance. It began in the late 1960s with Mary Daly's The Church and the second sex, and it quickly grew into an internationally recognised discipline. The research tasks were a wide field, they discovered women who had passed into oblivion and gave a new understanding of key women who had influenced the Christian churches. As written in the "Wörterbuch der Feministischen Theologie" it was considered necessary to read and brush the texts (especially the old and the new testament) "gegen den Strich", against the grain to discover forgotten women. ${ }^{1}$ These feminist scholars did not 
consider 'feminist theology' as an appendix to traditional theology but as a new theological concept. They worked on a concept of female emancipation based on a critical historical knowledge. Leonore SiegeleWenschkewitz formulated the research tasks: "An ecclesiastical history working with the gender category...would first of all need to historicise this problem-pointer," starting with the analytical tool-kit, "the concepts of feminism, patriarchy, androcentricity, sexism". Also in need of examination, according to her, were the effects of symbolic gender construction on the social organisation of the sexes, in thus she underlines the importance of the symbolic to religious fenomenons.

Siegele-Wenschkewitz in her quotation mentioned above talks about ecclesiastical history [Kirchengeschichte] rather than history of religion [Religionsgeschichte].

By the time feminist theology really got under way in Germany and in Austria, in the 1970s and 1980s with studies by Elisabeth Moltmann-Wendel, Elisabeth Gössmann, and as a result, female historians took up such ideas, the field of ecclesiastical history was changing radically. Hitherto, the research situation had been governed by the concept of ecclesiastical history, which did not distinguish between a confession and religion. From the 1970 onwards there was a change of paradigm with the research interest growing in the history of religion as social history. Research with a social-history slant turned with great enthusiasm to the question of 'popular religion', investigating the oral and written aspects of religious practices, belief in miracles, and the consequences of enlightened elite religions. The research questions focused on the social structure of religions and its meaning to men and women, without distinguishing between the 'superstitious' and the 'true' values as it was the case before. Many ideas also came from religious sociology. ${ }^{2}$ Women's and gender history found therefore a field of study that was very much on the move, even if (and this goes for the nineteenth and twentieth centuries for the German speaking countries) it was not a particularly large one. Religion, in contemporary history at least, was not a subject that filled the journals. In this feminist historians did not differ from social historians at least in Germany and in Austria. Other problems seemed to be of greater significance than religion, which in the context of a process of secularisation appears diluted; it was also not covered by modernisation theory, and in the field of nationalism-research it is seen as anticipating the cult of the nation and being extinguished later on. Women's history, in addressing religion in the nineteenth and twentieth centuries, conformed to these historiographical givens in that, as Sylvia Paletschek wrote in 1990, it "screened out previously religious questions". Other European countries had different traditions as for instance Italy and Great Britain. This was not only due to the power of the catholic church in Italy or of anglican church and the diversity of religious movements in Great Britain, but it was the effect of methodological questions too. An anthropological perspective made religions and their impact to history transparent; social and cultural anthropologues traditionally analised religious practices as a most important step to understand a social order and human relations. For women and gender historians this was a similar constellation; in Germany and in Austria at least for contemporary history they hesitated to consider religion a topic of relevance. They had to discover first, that over the centuries, theological thought systems, religious texts and images, and religious ideas and practices have produced a large body of material that reveals the many-layered as well as paradox significance of gender in religion: women were excluded from the offices on the one hand and found their specific spaces in the religious context on the other. Monasteries as well as the broad field 
of charity gave them potentially greater possibilities for public agency than they found in other areas of society and cultureat least until the introduction of women's suffrage and the opening of higher education to women.

In the 1990 the situation changed and is still changing and today we are testifying a process of a reeavaluation of religion in society and historiography; due in large part to the growing political and social importance of Islam. From the broad range of possible questions and investigations, I will first take up two historiographic examples, the religious women's movements and the debate on the "feminization of religion" which should give us an insight to important part of the discussions in the last twenty years. I can only briefly touch other historiographic topics. In the third part I focus on a field of recent research interests, that is to say on interreligious relationships, namely on the religious conversions.

\section{RELIGIOUS WOMEN'S MOVEMENTS}

An area on which studies in the history of religion by German and American women historians have concentrated a lot of research are the religious women's movements. This form of organisation is of interest to women's history for a variety of reasons. On the one hand it belonged to a long tradition of charitable activity which was regarded as religious obligation for men and women. The women's associations, which were founded at the beginning of the nineteenth century had patriotic and philantropic aims; by their organisation as associations they differed from the former groups of religious women who did charitable work. The associations gave them new possibilities to organize in an autonomous way and to gain public importance; for instance as early as 1816 the "Israelitischer Frauenwohltätigkeitsverein" was founded in Vienna.

The first study of a religious women's movement was Marion Kaplan’s “The Jewish Feminist Movement in Germany. The Campaigns of the Jüdischer Frauenbund 1904-1938". ${ }^{3}$ It was not a coincidence that it was a book written by an American as American women's studies had a great impact on the German and Austrian ones and only later on the situation changed. Kaplan's book set a standard for subsequent studies, not only in the sense of its historiographic quality but also in setting the main problems and questions. Jewish womens's history was different from the catholic and protestant one as it was part of a history of marginalization and jewish men and women strived for legal emancipation which was denied them on religious grounds in many countries of Europe untill the second part of the $19^{\text {th }}$ century and when taken away again in the $20^{\text {th }}$ century following the Nurenberg laws. But jewish women fought as did protestant and catholic ones - much later - for greater equality in the sphere of religion. In her book, Marion Kaplan described a hitherto unexamined story (that of a major Jewish women's organisation) and showed how women, pushing for religious change, had quickly come up against limiting factors, although religion remained for them an important aspect of their identity. The resultant tensions constitute a set of problems that can also be encountered in connection with other religious women's movements. But we lack comparative studies although there are books on other religious women's movements too.

In her book on the Protestant women's movement, published in 1988, Doris Kaufmann particularly stressed the importance of that movement for the emancipation of the women who belonged to it, although she also highlighted the tension between feminist concerns and gender asymmetries that had ecclesiastical backing. This was also true with regard to the Jewish women's movement. However, in contrast to the latter, protestant women were well able to wield political influence, and the question 
of power was decisive. I refer to the notorious rightward shift of the "Federation of German Women's Associations" [Bund Deutscher Frauenvereine] as a result of the accession of the German Protestant Women's Federation [Der Deutsch-Evangelische Frauenbund] which stressed morality [Sitttlichkeit] and opposed the reform of the abortion law and the introduction of voting for women in Germany. Their dependence on the clergy made religious women's movements vulnerable to exploitation by politico-ecclesiastical interests. This also had repercussions so far as the concept of female emancipation was concerned. To quote Ursula Baumann:

From the outset, the aggressive stance of ecclesia-stical Protestantism vis-à-vis all tendencies that aimed at dismantling the hierarchy of gender relations went hand in hand with a strategy of utilising women for the Home Mission, which became institutionalised around the middle of the century. By applying the bourgeois model of love to society as a whole, it was hoped that mobilising women's "love activity" would halt the flight from the churches and cushion class antagonisms. 4

However, it must be stres-sed that religious women's movements are not wholly accounted for by this fact that is the fixing of the role of women as the re-presentatives of love, because religion offers a wide variety of interpretative possibilities .

The same is true of the 'Catholic women's federation' that Gisela Breuer studied in a book published in 1998.5 Unlike the women's movements mentioned hitherto, this one never joined the "Federation of German Women's Societies". The same thing happened in Austria, where the "Imperial Catholic Women's Society" never became a member of the "Federation of Austrian Women's Societies". [Bund Österreichischer Frauenvereine]. Presumably, then, this had to do with the differently constituted concepts of emancipation en- tertained by Catholic and interconfessional women's movements rather than any fear on the part of Catholics of been marginalised in a predominantly protestant organisation. The question of the importance of religious women's movements not only for female emancipation, for combating poverty, or for their importance to society, but also for the religions themselves and their claim to offer explanations and guidance is one that Sylvia Paletschek raised in her 1990 volume "Frauen und Dissens. Frauen im Deutschkatholizismus und in den freien Gemeinden 1841-1852" ["Women and dissent. Women in German Catholicism and in the Free Churches 1841-52"].6 In the book, she establishes that dissenters contributed towards secularisation. "The religious opposition movement of the (18)40s can be seen as a landmark in the process of de-Christianisation and the relaxation of the hold of the churches. It popularised religious criticism, the rational thinking of the Enlightenment, and the scientific world-view." (Paletschek 1990) On the other hand she argues, it would also have facilitated a transition to unattached religiousness. The same cannot be said of the other religious women's movements; possibly they strenghtened the ties to religion, but first it would be necessary to enquire about the consequences that these mass movements had on the role of religion in society.

The studies of women's religious movements in the nineteenth and twentieth century highlighted the tension between feminist concerns, gender asymmetries, segregation and exlusion of women in the churches and the difficulty to formulate a concept of emancipation. (no right to vote in the community, no ecclesiastical offic etc.) They emphasized the role of experience acquired in these associations by its female members, but underlined too their political instrumentalization by politicised churches in the early decades of the $20^{\text {th }}$ century. 
THE DEBATE ABOUT THE

\section{'FEMINIZATION OF RELIGION'}

The stimulus behind this area of research came from American studies such as Barbara Welter's on the feminisation of religion in America and Bonnie G.Smith, the ladies of the leisure class. ${ }^{7}$ In 1988 the subject was taken up by McLeod, in 1990 by Sylvia Paletschek, in 1994 by Rebekka Habermas, and in 1995 by Friedrich Schlögl and Irmtraud Götz von Olenhusen. ${ }^{8}$ Despite their very different approaches, all these studies found the same fenomenon: in the transition from the ancien régime to bourgeois society a 'familiarisation' of religion took place in the sense that from the turn of the century (18./19.) onwards the place where religion was handed down and practised was the family, the public character of religious rituals being a thing of the past (Habermas). This situation (it is alleged) had presented women with new opportunities for exercising influence, and men, because of their greater integration in the world of work, had been affected by the process of secularisation earlier than women. The notion of feminisation as familiarisation (Thomas Mergel) fits into the concept of a polarisation of gender characters that with the separation of incomegeneration and family life had identified the family as the only sphere within which women could wield influence (Hausen). Historical research has come up with a wealth of supporting evidence for this process: migrations (McLeod) that have made women the transmitters of cultural and religious practices, testamentary and mass-endowment practices, the choice of the religious life, which retained both its attractiveness for women far longer than for men. Under the impression of an enormous loss of power, the churches (Rudolf Schlögl tells us) were prompted to modify their hitherto somewhat negative anthropology of women. Women trusted for longer in God's mercy and justice and in the mediating power of the churches, while men placed more faith in their own moral power. Women dominated in pilgrimages and in charitable 'brotherhoods'; they played a central role in revivalist movements

The discussion on the 'feminisation of religion' continues. What has this debate contributed to gender studies? It has undoubtedly helped us to reach a better understanding of the 'polarisation of gender characteristics' that took place in the early nineteenth century and highlighted the important part played by religion in that process, stressing the importance of home and family to women. It has not, on the other hand helped us to understand phenomenons like the rise of women's congregations in the $19^{\text {th }}$ century, and the role of women in the revivalist movements of the late eighteenth and the early nineteenth century, who gained spiritual leadership in these groups and transcended the cultural barriers they were expected to respect. Back in 1963, it was E.P. Thompson who had discussed the prophetess Joanna Southcott in his The Making of the English Working Class, ${ }^{9}$ giving her a place in the history of the working class; he did not do it without irony but later on feminst historians had deepened the studies on the role of women in revivalist movements showing their way to prophetism which gave them a voice in the public. This way to recognition had a long tradition in the history of the saints. Gabriella Zarri has shown this in her book on the "sante vive", 10 (living saints), on women who were considered saints during their lifetime. In the revivalist movements women managed to gain leadership as the movements refused the intervention of the traditional hierarchy and searched a spiritual reincarnation. ${ }^{11}$ Informal religious structures gave women more chances to gain leadership; I do not think that we can call feminization of religion what gave women a chance to appropriate religious language and pronounce it in the public.

The meaning of religion to women and 
men is certainly studied in a vast range of topics, as for example the history of nunneries which gave women a space for their own and where they found possibilities to read and study and write religious texts or letters; on the other hand these writings were controlled by priests and very often family strategies decided very often about a woman's entrance into the nunnery. ${ }^{12}$ The relationship between priests and women and specifically nuns and priests was a difficult one. Jules Michelet, the great French historian, considered the catholic priest the rival of the husband because of being the master of the female soul. "Le prêtre tient l'âme, dès qu'il a le gage dangereux des premiers secrets, et il la tiendra de plus en plus". In his book "Le prêtre, la femme et la famille" first published in 1845 he described in particular the confession as the most dangerous relationship because the husband was excluded from the conversation. Researchers underlined how the role of the priest in catholicism differed from that in protestantism in a decisive way. Living in celibacy or living with wife and children made a different place in community life. ${ }^{13}$ Still we lack comparisons concerning the role of women in catholicism and protestantism.

\section{INTERRELIGIOUS GENDER RELATIONS}

\section{AND RELIGIOUS CONVERSIONS}

In an article in the German ethnographic journal Zeitschrift für Volkskunde, Werner Schiffauer examines the currently prevalent "fear of difference", as he calls it, which comes out in such terms as "othering". "We have lost sight of the self-evident fact that ethnic groups, religious communities, and even cultural regions exist that we can then examine" - particularly since they are deemed images of reality that say more about those who produced them than about those they are meant to describe. One consequence of this development has been, according to Schiffauer, "the topicali- sation and conceptualisation of the space between cultures. This means addressing the question of how processes of intercultural exchange and interaction can be described." (Schiffauer 1992) 14

What does this mean for the relationship between gender and history?

Globalization, migration and discussions of multiculturalness have imbued these forms of relationships with a new topicality. European gender relations have been considerably influenced by attempts at separation through bans on relationships as it is for instance the case of the prohibition of the disparitas cultus, the ban on marriage for reasons of religious difference. (Christian-jews, moslems, but also between the confessions as in the famous "Mischehenstreit in Köln") This ban was formulated by the religions themselves though in different ways and taken up by the civil law until the introduction of the civil marriage. In this situation men and women of different religions could not marry each other, in some parts of Europe this lasted until the $20^{\text {th }}$ century.

One result of this situation was the necessity and practice of religious conversions. Sure, there are other reasons for conversions than these legal aspects and sure, in the late $20^{\text {th }}$ century the situation has changed, as Monika Wohlrab-Sahr ${ }^{15}$ has shown: Today it is very often marriage which leads to conversion and not conversion which enables to marry. But both cases have in common what Wohlrab-Sahr underlines: Conversions have "biographical functions", a "biographical rationality". And they have their social and gender functions.

I will give an example from Vienna in the first half of the nineteenth century, the great time of conversions. ${ }^{16}$ Never before and after so many jews changed their religion. In the Restoration Vienna of what is called the Vormärz or 'Pre-March' period between 1815 and the revolution of March 1848, more Jews quit their religion than 
ever before or since, with one in eight accepting baptism. ${ }^{17}$

The increase of conversions was mainly due to the fact, that marriages between Jews and Christians were not possible, but we have to consider too that jews were excluded from many professions. And until 1868 it was not possible for christians to convert to judaism. But this legal situation was the same in the eighteenth century and there were few conversions. In the early ninteenth century more jews than before converted and presumably wanted to marry christians. Who were they? More men than women changed their religion and considered it possible to change the religion of their fathers. Women were more hesitant to leave it. Men had more contacts outside of the family and more men married christian women. They were mainly between 20 and 29 years old and from the middle class. ${ }^{18}$ We can therefore interpret this process as a form of rapid secularization and detraditionalization in the jewish population. But it is more precise to take it as a sign of the growing conviction that religions were convertible and that the relationships in the jewish community had loosened, at least for some persons. It is a new form too to handle the constraints jews had to live with. There are legal, personal, social, political, and cultural dimensions to any change of religion.

It requires a change of identity and new forms of belonging and distinctions; it produces social and cultural conflicts.

At the end of the $20^{\text {th }}$ century the situation is different: there are no legal hindrances to marry and to change religions and there are more women who convert today to Islam in the US and Germany. A re-moralization of life is a strong motive for these conversions.

For the early $19^{\text {th }}$ century Ego documents are of special interest insofar as they follow a certain conversion narrative demonstrating an account giving putting oneself in the great traditions of conversion- telling (Paulus, Augustinus); but they are of interest too because they demonstrate convictions, persuasions and their rhetoric. Lets have a look on Dorothea Schlegel who converted from the jewish religion first to protestantism then to catholicism in 1808 together with her husband Friedrich Schlegel; but she wanted the conversion of her two sons from the first marriage too.

Dorothea Schlegel, apparently, did not see her conversion from Judaism to Christianity as marking a change in her life, or rather her writings do not admit such an interpretation. In her journal for 1804, describing her conversion to Protestantism, she entered: "6 April baptised and wed in the Swedish Chapel in Paris. On Trinity Sunday, 27 May, took communion for the first time in Paris, at the Swedish Chapel."19 On 16 April 1808 she wrote: 'Made profession of faith at Altar of the Madonna in Cologne cathedral. In the presence of Dean Dümont, seminary principal H. Foerster, chaplain Gumpert, and the Kirchenmeister, H. Debeche.' On 18 April: “Attended Holy Communion at the seminary. Our marriage blessed by the Church in the presence of the aforementioned persons."20

In the brief text devoted to the external course of events (in connection with Dorothea's conversion to Protestantism in Paris in 1804), baptism was followed by marriage and communion. The description of her conversion to Catholicism four years later (in 1808) goes further in noting the setting (the Altar of the Madonna in Cologne cathedral) and giving the names of those present, though their function in terms of canon law is not specified. Dorothea wrote no more in her journal about the baptism and marriage ceremonies.

In a letter to her sister-in-law and brother-in-law she went into greater detail about the former event:

At three o'clock this afternoon I was baptised in Paris, and immediately afterwards we were wed, very quietly, with a couple of friends as 
Jomfru Maria (scanpix) 
witnesses; in the private chapel of the Swedish embassy and by embassy chaplain Gambs, a very good man who later became a great friend of ours. He also instructed me in Christianity over the winter. He conducted both ceremonies in German [my underlining; E.S.], which I was very glad of; it would not have had its full importance for me in French. ${ }^{21}$

Regarding what her conversion meant to her, Dorothea wrote nothing. The letter does not show whether her praise of the priest who for her baptism and marriage ceremony had spoken German rather than French indicated a favouring of her mother tongue or a low opinion of French. However, the passage does make clear the importance of language for those taking part in the performance of religious ceremonies.

In addition, Dorothea's letter to her sister- and brother-in-law mentioned the need to say nothing about her going over to Christianity out of consideration for her former husband, Simon Veith, "who behaves towards us with courtesy and charm on every occasion and certainly deserves such protection" (ibid). Her mother-in-law was to be told, but no one else.

The purpose of such concealment was to prevent ruptures with friends. Dorothea represented conversion as a matter concerning only a person's inner life; she made no mention of the fact that the law prevented Judeo-Christian marriages or rather made them more difficult. ${ }^{22}$ Before civil marriage was introduced in France in 1792, marriages between Christians and nonChristians were forbidden. Civil marriage abolished that ban. Dorothea Veit and Friedrich Schlegel could have had a civil wedding in Paris, but they did not. Dorothea need not have converted to Christianity in order to marry Friedrich; she wished to convert. Nevertheless, her conversion fell into a tradition that was shaped by a ban. In Germany, it was not until the introduction of civil marriage in 1874 that the ban was fully lifted.
To prevent ruptures with friends and the family was even more important after Friedrich and Dorotheas Schlegels conversion to catholicism. They subsequently kept the fact secret; Friedrich Schlegel's mother was to hear nothing of his conversion to catholicism. Friedrich even asked his brother to silence the rumour to that effect, writing:

Should our mother unfortunately hear this idle talk, please do everything you can to calm her. Just remind her how often I have been slandered and gossiped about in the press but how each time I have won through in the end, adding permanently to my reputation. ${ }^{23}$

However, Friedrich Schlegel's attempt to conceal his conversion from his brothers, his mother, and the wider world, to regard religion (initially) not as a social phenomenon but as a purely private and personal matter, met with failure. He overlooked the fact that every conversion, and especially his own, was a political act that aroused public interest. In 1808 religion was not a personal matter. In letters she had been writing since 1806 Dorothea Schlegel had thought about converting to Catholicism and the possibility of and necessity for keeping it secret, and both Schlegels had been considering going over to Rome since 1804. The reason why this was difficult was that Dorothea was a divorced woman and canon law placed obstacles in the way of remarriage according to the Catholic rite. ${ }^{24}$ Reactions might also be expected in the public sphere. Yet Dorothea was convinced that concealment was possible. "If you do not yourself deliberately proclaim it in public, there will not be the slightest fuss." They could attend mass before daybreak, she offered. ${ }^{25}$ The Schlegels became Catholic converts in Cologne in 1808; Dorothea was 44 years old, Friedrich thirty-six. There were political considerations, too, suggesting concealment. Friedrich Schlegel was 
on the point of moving to Vienna, where he hoped to obtain well-paid employment in the academic world or in the civil service. His conversion might give the impression that it constituted his ticket of admission to a career in the Austrian capital. This was in fact how it was seen by many of his contemporaries, including Catholic friends. One friend wrote that he had expected a conversion to Catholicism for a long time,

but at this moment, when such a conversion, which was purely a matter of conscience, could so easily look like outward intention, provoking huge disgust and giving great offence, we found it difficult to understand his taking so important a step. ${ }^{26}$

When a person changes his or her religion, the former religious communities take offence; this was as true of Protestantism as it was of Judaism. 'Apostates' were aware of this and therefore often sought to keep their action secret - which on the other hand was precisely what they had no wish to do. Because the intention behind that action was to reposition oneself in society and start a process of integration into a new social environment. The life of a convert of either gender around 1800 was a delicate balancing-act. In Austria for jews and protestants.

Europe was at war, Napoleon's policies were doing away with structures steeped in tradition, not least in the area of religion and the church, and in Vienna, which the French occupied from May 1809, Dorothea expected great things. She drew her son Jonas's attention to these, placing religion, morality, and aesthetics in a single context:

"All the events of our time are working towards a major decision; let us, duly prepared and united, go out to meet it [...] My son, for you a new world will arise, and only through Christianity will you be guided to- wards harmony with yourself and a loving union with mankind [...] There is no art, no painting for him who knows not Christianity, and you cannot hope to progress along any other path. For whoever does not believe, does not hope, does not love - for him, nature is a desert in which he sees nothing but himself; for him, in other words, even art is but a mirror of his arrogant conceit." (Schlegel i 27 Raich 1881)27

Another key concept in the argument that Dorothea Schlegel developed with the aim of convincing her sons of the need to convert was that of unity for the 'general good' [das allgemeine Beste]. The 'general good' meant becoming involved in the nationalist movement and joining the fight against Napoleon:

"The philosophy of indifferentism is not that of Christianity. So I cannot of course blame Veit [ her former husband] for having fashioned his conviction from it; but may it not affect your minds, God and His saints preserve you from that! Neither shielding nor seeking its own benefit or its own pleasure, hoping, suffering, and dying for what is right and holy - that is the morality of the faith [Christianity] to which you will be converting, and in the attainment of which may God give you strength and courage and patience. I pray for you daily, dear children.” Ibid, 345 $28)^{28}$

In Dorothea Schlegel's eyes, what was right and holy in 1809 included the war against Napoleon that Austria had just declared. She harnessed both Christian morality (selfsacrifice, partiality) and the nationalist zeal currently inspiring the fight against France. Her letter illustrates how easily religion amalgamated with nationalist politics. Benedict Anderson considers that the idea of the nation and subsequently nationalism itself sprang from the loss of religious power. ${ }^{29}$ Religion nevertheless I would add constituted a resource of nationalism. In 
the case of Christianity, this happened as a result of the iconographic, literary, and dogmatic traditions that gave national heroism a historical depth and a religious foundation, in which women had a special function. ${ }^{30}$ In the case of Doro-thea Schlegel we see her eager to become part of the nation, to dissolve herself in it.

It can only be the work of further research to dicuss the gender aspects of conversions, not only in a quantitative aspect but in a qualitative aspect too. Are there differences of meaning, of conversion narratives? I would say, that interreligious gender relationships and as a part of it, the history of conversions open new dimensions to a feminist history of religion.

\section{NOTER}

1. Wörterbuch der Feministischen Theologie (ed.), (1991): Elisabeth Gössmann, Elisabeth Moltmann-Wendel, Herlinde Pissarek-Hudelist, Ina Praetorius, Luise Schottroff, Helen SchüngelStrautmann, Gütersloh, 129.

2. Niklas Luhmann, Alois Hahn, Peter Berger.

3. Connecticut 1979. It was translated in German 1981: Die jüdische Franenbewegung in Deutschland. Organisation und Ziele des Jüdischen Frauenbundes 1904-1938.

4. Ursula Baumann, Protestantismus und Framenemanzipation in Deutschland 1850-1920, Frankfurt a.M.270.

5. Gisela Breuer (1998), Franenbewegung im Katholizismus. Der katholische Franenbund 19031918, Frankfurt.

6. Sylvia Paletschek (1990), Frauen und Dissens. Franen im Deutschkatholizismus und den freien Gemeinden 1841-1852, Göttingen.

7. Barbara Welter, "Frauenwille ist Gottes Wille. Die Feminisierung der Religion in Amerika, 18001860", in: Claudia Honegger, Bettina Heinz ed. (1981), Listen der Ohnmacht. Zur Sozialgeschichte weiblicher Widerstandsformen, Frankfurt a.M., 326-356 Published in English: "The Feminization of American Religion, 1800-1860", in: William O'Neill ed. (1981), Problems and Issues in American Social History, Minneapolis 1974. Bonnie G. Smith (1981), Ladies of the Leisure Class. 8. Irmtraud Goetz von Olenhusen ed. (1995), Wunderbare Erscheinungen. Frauen und katholische
Frömmigkeit im 19. und 20. Jabrhundert, Paderborn, Rebekka Habermas, "Weibliche Religiositätoder: Von der Fragilität bürgerlicher Identitäten", in: Klaus Tenfelde und Hans Ulrich Wehler: Wege zur Geschichte des Bürgertums. Vierzehn Beiträge, Göttingen, Hugh McLeod, "Weibliche Frömmigkeit-männlicher Unglaube? Religionen und Kirchen im bürgerlichen 19. Jahrhundert", in: Ute Frevert Hg. (1988), Bürgerinnen und Bürger. Geschlechterrollen im bürgerlichen 19. Jahrhundert, Göttingen, 134-156.

Thomas Mergel, "Die subtile Macht der Liebe. Geschlecht, Erziehung und Frömmigkeit in katholischen rheinischen Bürgerfamilien 1830-1910", in: Goetz von Olenhusen (1995), Frawen unter dem Patriarachat der Kirchen, Stuttgart, 22-47, Sylvia Paletschek (1990), Frawen und Dissens, Frauen im Deutsch-katholizismus und in den freien Gemeinden 1841-1852, Göttingen. Rudolf Schlögl, "Sünderin, Heilige oder Hausfrau? Katholische Kirche und weibliche Frömmigkeit um 1800", in: Irmtraud Götz von Olenhusen ed. (1995), Wunderbare Erscheinungen. Frauen und katholische Frömmigkeit im 19. und 20. Jahrhundert, Paderborn, 13-50.

9. E.P.Thompson (1963): The Making of the English Working class. On Southcott see chapter II/11 10. Gabriella Zarri (1990): Le sante vive. profezie di corte e devozione femminile tra `400 e `500, Torino.

11. To give some examples: Edith Saurer, "Die Autobiographie des Thomas Pöschl. Erweckung, weibliche Offenbarung und religiöser Wahn", in: Edith Saurer ed. (1995), Die Religion der Geschlechter. Historische Aspekte religiöser Mentalitäten (L’Homme Schriften. Reihe zur Feministischen Gschichtswissenschaft 1) Wien,169-212. Irmtraud Götz von Olenhusen ed. (1995), Wunderbare Erscheinungen. Frauen und katholische Frömmigkeit im 19. und 20. Jabrhundert, Paderborn. Marina Caffiero, "Le profetesse di Valentano", in: Gabriella Zarri ed. (1991), Finzione e santità tra medioevo ed età moderna, Torino, 493-520.

12. There is a huge literature on different aspects of nunneries. Concerning the control of the writings of nuns, vedi Sara Cabibbo, "Ignoratio Scripturarum ignoratio Christi est". Tradition und Praxis des Schreibens in den Texten von Klosterfrauen im 17. Jahrhundert, in: Saurer, 95-136, Christine Schneider (2006), Kloster als Lebensform, Wien, forthcoming. Yvonne Maria Werner ed. (2004), Nuns and Sisters in the Nordic Countries after the Reformation - A Female Counter - Culture in Modern Society, Uppsala.

13. Luise Schorn-Schütte, ed. (1997), Evangelische 
Pfarrer: zur sozialen und politischen Rolle einer bürgerlichen Gruppe in der deutschen Gesellschaft des 18. bis 20. Jabrhunderts, Stuttgart. Concerning the catholic priest Vedi Edith Saurer, "Frauen und Priester. Beichtgespräche im frühen 19. Jahrhundert”, in: Richard van Dülmen ed. (1990), Arbeit, Frömmigkeit und Eigensinn, Frankfurt a.M., 141170.

14. Werner Schiffauer, "Die Angst vor der Differenz. Zu neuen Strömungen in der Kulturanthropologie", in: Zeitschrift für Volkskunde 92 (1996) 20-32

15. Monika Wohlrab-Sahr (1999), Konversionen zum Islam in Deutschland und den USA, Frankfurt and Hubert Knoblauch, Volker Krech, Monika Wohlrab-Sahr ed. (1998), Religiöse Konversionen. Systemische und fallorientierte Studien in soziologischer Perspektive, Konstanz.

16. Edith Saurer, "Romantische Konversionen. Religion und Identität in der Wiener Romantik", in: Christian Aspalter et alii ed., Die Spur der Romantik in Wien, forthcoming.

17. Anna L. Staudacher (2002), Jüdische Konvertiten in Wien 1782-1868 1, Frankfurt a.M., 260.

18. Staudacher 1, 193-200

19. J.M. Raich, Dorothea Schlegel geb. Mendelssohn und deren Söhne Johannes und Philipp Veit. Briefwechsel 1, Mainz, 1881, p. 130.

20. ibid., p. 237 , note 1 .

21. Dorothea Schlegel to Charlotte and Ludwig Emmanuel Ernst, 6 April 1804, in: Josef Körner (1936), Krisenjabre der Frühromantik. Briefe aus dem Schlegelkreis 1, Brno, p. 70.

22. Kerstin Meiring (1998), Die Christlich-Jüdische Mischehe in Deutschland, 1840-1933, Hamburg.

23. Körner, Krisenjahre, 542; Friedrich Schlegel to Karl Schlegel, 14 May 1808

24. ibid., 563 f.; Dorothea Schlegel to August Wilhelm Schlegel, Cologne, 30 June 1808.

25. Raich, Dorothea Schlegel 1. 196; Dorothea Schlegel to Friedrich Schlegel, Cologne, 1806 . 26. Sulpiz Boisserée (1978), Tagebü̈cher 1, Darmstadt, 39.

27. J.M.Raich, Dorothea Schlegel 1, Mainz 1881, 327; Dorothea to her son Jonas in Dresden, 11 February 1809.

28. ibid., 345, Dorothea to her sons in Dresden, Vienna, 22 April 1809.

29. Benedict Anderson (1991), Imagined Communities: Reflections on the Origin and Spread of $\mathrm{Na}$ tionalism, London and New York, (revised edition).

30. Alberto M. Banti (2000), La nazione del Risorgimento. Parentela, santità e onore alle origini dell'Italia unita, Torino.

\section{LITTERATUR}

- Margaret Lavinia Anderson, "the limits of secularization: on the problem of the catholic revival in nineteenth century Germany", in: The Historical journal 38 (1995) 647-670

- Ursula Baumann (1992), Protestantismus und Frauenemanzipation in Deutschland 1850-1920, Frankfurt a.M.

- Ida Blom, Das Zusammenwirken von Nationalismus und Feminismus um die Jabrhundertwende: Ein Versuch zur vergleichenden

Geschlechtergeschichte, in: Heinz-Gerhard Haupt, Jürgen Kocka Hg., Geschichte und Vergleich. Ansätze und Ergebnisse international vergleichender Geschichtsschreibung, Frankfurt/M 1996, 315-338 - Gisela Breuer, Frawenbewegung im Katholizismus. Der katholische Frauenbund 1903-1918, Frankfurt 1998

- Sara Cabibbo, "Ignoratio Scripturarum ignoratio Christi est". Tradition und Praxis des Schreibens in den Texten von Klosterfrauen im 17. Jahrhundert, in: Saurer, 95-136.

- Dagmar Freist, “Zwischen Glaubensfreiheit und Gewisssenszwang. Das Reichsrecht und der Umgang mit Mischehen nach 1648", in: Ronald G.Ash u. (2001), Frieden und Krieg in der frïhen Neuzeit. Die europäische Staatenordnung und die außereuropäische Welt, München.

- Ulrike Gleixner, "Pietismus, Geschlecht und Selbstentwurf. Das „Wochenbuch" der Beate Hahn, verh. Paulus (1778-1842)", in: Historische Anthropologie 10 (2002) 76ff.

- Irmtraud Götz von Olenhusen u.a. (1995), Frawen unter dem Patriarchat der Kirchen. Katholikinnen und Protestantinnen im 19. und 20. Jahrbundert, Stuttgart.

. Irmtraud Götz von Olenhusen ed. (1995), Wunderbare Erscheinungen Frauen und katholische Frömmigkeit im 19. und 20. Jahrhundert, Paderborn.

- Irmtraud Götz von Olenhusen (1994), Klerus und abweichendes Verhalten. Zur Sozialgeschichte katholischer Priester im 19.Jahrhundert: Die Erzdiözese Freiburg, Göttingen.

- Karin Hausen, "Die Polarisierung der "Geschlechtscharaktere". Eine Spielgelung der Dissoziation von Erwerbs- und Familienleben", in Werner Conze ed. (1976), Sozialgeschichte der Familie in der Neuzeit Europas, Stuttgart. - Marion Kaplan (1981), Die Jüdische Franenbewegung in Deutschland Organisation und Ziele des jüdischen Frauenbundes 1904-1938, Hamburg. - Doris Kaufmann, Frauen zwischen Aufbruch und Reaktion. Protestantische Franenbewegung in der ersten Hälfte des 20. Jahrbunderts, München 1988 
- Doris Kaufmann (1984), Katholisches Milieu in Münster 1928-1933. Politische Aktionsformen und geschlechtsspezifische Verhaltensräume, Düsseldorf. - Hugh McLeod (1988), Weibliche Frömmigkeitmännlicher Unglaube? Religionen und Kirchen im bürgerlichen 19.Jahrhundert, in: Ute Frevert ed., Bürgerinnen und Bürger. Geschlechterrollen im bürgerlichen 19. Jahrhundert, Göttingen, 134-156. - Kerstin Meiring (1998), Die christlich-jüdische Mischehe in Deutschland 1840-1933, Hamburg. . Thomas Mergel, "Die subtile Macht der Liebe. Geschlecht, Erziehung und Frömmigkeit in katholischen rheinischen Bürgerfamilien 18301910", in Goetz von Olenhusen ed., Frawen unter dem Patriarachat der Kirchen, 22-47.

- Sylvia Paletschek (1990), Framen und Dissens, Frauen im Deutschkatholizismus und in den freien Gemeinden 1841-1852, Göttingen.

- Edith Saurer ed. (1995), Die Religion der Geschlechter.Historische Aspekte religiöser Mentalitäten, Wien.

- Edith Saurer, "Frauen und Priester. Beichtgespräche im frühen 19. Jahrhundert", in: Richard van Dülmen ed. (1990), Arbeit, Frömmigkeit und Eigensinn, Frankfurt a.M., 141-170.

- Werner Schiffauer, "Die Angst vor der Differenz. $\mathrm{Zu}$ neuen Strömungen in der Kulturanthropologie", in: Zeitschrift für Volkskunde 92 (1996), 2031 .

- Rudolf Schlögl, "Sünderin, Heilige oder Hausfrau? Katholische Kirche und weibliche Frömmigkeit um 1800", in: Irmtraud Götz von Olen husen ed. (1995), Wunderbare Erscheinungen. Frauen und katholische Frömmigkeit im 19. und 20. Jahrbundert, Paderborn, 13-50.

- Luise Schörn-Schütte, Walter Sparn ed. (1997), Evangelische Pfarrer. Zur sozialen und politischen Rolle einer bürgerlichen Gruppe in der deutschen Gesellschaft des 18. bis 20. Jahrhunderts, Stuttgart. - Leonore Siegele-Wenschkewitz, "Die Rezeption und Diskussion der Genus-Kategorie in der theologischen Wissenschaf", in: Hadumod Bußmann, Renate Hof ed. (1995), Genus. Zut Geschlechterdif- ferenz in den Kulturwissenschaften, Stuttgart, 60110.

- Leonore Siegele-Wenschkewitz, Gury SchneiderLudorff, Beate Hämel, Barbara Schoppenreich ed. (1998), Frawen Gestalten Geschichte. Im Spannungsfeld zwischen Religion und Geschlecht, Hannover.

-Weib und Seele (1998), Frömmigkeit und Spiritualität evangelischer Franen in Württemberg. Katalog zur Ausstellung, Ludwigsburg.

- Yvonne Maria Werner ed. (2004), Nuns and Sisters in the Nordic Countries after the Reformation A Female Counter - Culture in Modern Society, Uppsala.

\section{SUMMARY}

The article consists of two parts. In the first it gives an insight into the historiography concerning gender and religion primarily in Austria and Germany since the 19th century for the last twenty years about. Researches on religious women's movements are discussed exemplarily as well as the debate on the 'feminization of religion', which had an great impact on studies on religion in the last years. The second part of the text discusses religious conversions as an example for interreligious (gender) relationships taking into account the longlasting ban on interreligious marriages. The example concerns the conversion of the romantic Dorothea Schlegel, of her husband Friedrich Schlegel and her two sons of the first marriage (Philipp and Johannes (Jonas) Veit) and analyses the conversion narratives of her writings.

Edith Saurer

Professor of History, University of Wienna 